\title{
Monitoring Water Contaminants: a Case Study for the Republic of Moldova
}

\section{Lucia Nastasiuc $^{1}$, Oleg Bogdevici ${ }^{1}$, Overcenco Aureliu${ }^{1}$, Elena Culighin ${ }^{1}$, Anatoli Sidorenko ${ }^{1}$, Ashok Vaseashta ${ }^{2,3 *}$}

\author{
${ }^{1}$ Academy of Sciences of Moldova, MD-20281 Chisinau, MOLDOVA \\ ${ }^{2}$ Senior Fellow/Strategic Advisor, Institute for Advanced Sciences Convergence and international Clean Water Institute, \\ NUARI, Northfield, VT, USA \\ ${ }^{3}$ Vice Provost, Research, Molecular Science Research Center, Orangeburg, SC, USA
}

Received: 22 April 2015

Accepted: 23 July 2015

\begin{abstract}
Water quality monitoring is a major issue toward maintaining safety and security for many countries. Due to many contaminants present in surface water in the Republic of Moldova, groundwater monitoring has become an exclusive source of drinking and potable water for many cities. In this investigation, we determined chemical contaminants in groundwater bodies of the Prut River basin for groundwater classification. For this investigation, monitoring wells were sampled by several field trials. The results of the chemical analysis have been used for the preliminary identification, characterization, and classification of groundwater bodies. The chemical content of water shows the current status of groundwater bodies under investigation, thus validating the study on the importance of groundwater monitoring. We examined several heavy metals in the groundwater from a national monitoring network. One hotspot (contaminated region) is the old Chismichioi pesticide deposit, which was studied for the assessment of actual status of the surrounding territory. It is also one of the largest deposits of toxic substances in the Low Danube Euro region. The following spectrum of persistent organic pollutants was identified in the samples: DDE, DDD, DDT, a-HCH, b-HCH, and g-HCH. Several other toxic organic substances were also studied at this site, including PAHs, triazine pesticides, and some other heavy metals. The general conclusion about the situation around the Chismichioi deposit is that the level of pollution from the time of the origination (in 1979) has not changed, in general. The zones with high pollution levels should be eliminated and recommendations have been made for the mitigation of the negative impacts to the environmental and water resources in this area of Moldova. At the conclusion of this extensive investigation, similar studies are planned for other locations and surface water sources. This will provide a valuable tool for the Republic of Moldova and may be extended to other regions as well.
\end{abstract}

Keywords: groundwater monitoring, heavy metals, safety, environmental risk assessment

*e-mail: prof.vaseashta@ieee.org 


\section{Background}

Water management is important for countries with arid and semiarid climates. Climate change will most likely impact surface and groundwater balance and quality. Some models suggest that periods with extremely high precipitation or strong drought will occur more frequently and for longer durations. In this case, the respective integrated water resource management (IWRM) plays an important role in the economic development of every country. Undertaking the demand on water usage caused by agriculture is a main challenge to achieving the quality objectives of the Water Framework Directive (WFD) in Europe and in the Danube region. The WFD requires that an integrated monitoring program has to be established within each river basin district [1]. The Republic of Moldova has two principal basins that are transboundary, viz., the Danube River Basin with Romania and the Nistru River Basin with Ukraine. The Republic of Moldova has taken a decision to align its legislation more closely with that of the European Union. Within this context it also has taken on increased obligations in terms of river basin management.

Water resources are determined by a number of factors, including the amount of water received from precipitation, inflow and outflow in rivers, and the amount lost by evaporation and transpiration. The Republic of Moldova is located in southeastern Europe, in a region with insufficient precipitation, limited water resources, with tempered climate and relatively limited humidity [2]. In recent history, precipitation has become very unstable. As an example, 2007 was characterized by a strong drought with average precipitation volume of $62-170$ $\mathrm{mm}$ (35-85\% of yearly volume). Three out of every 10 years are drought-afflicted in Moldova. Within the same time period, tremendous downfalls also occurred with precipitation exceeding $200 \mathrm{~mm}$ per day.

Natural components include precipitation, river flow, and groundwater levels, and artificial components include abstractions and discharges. The quality and quantity of natural water resources is sufficient in general for the sustainable development of Moldova. There are transboundary rivers such as the Prut and Nistru, small rivers and lakes, and shallow and deep groundwaters. However, water resources are irregularly distributed throughout the country. The southern part of Moldova is in a semiarid zone with a deficiency in good water for different purposes: drinking, irrigation, industrial use, etc. It is noted that more than $30 \%$ of groundwater sources that provide the city with drinking water do not meet the quality requirements for chemical indicators and that more than $70-80 \%$ of wells are not suitable and often dangerous to use for drinking purposes. The shallow groundwaters in the greater part of the nation's territory are polluted by anthropogenic sources, in particular nitrates.

The semiarid climate in Moldova makes it necessary to use groundwater resources in conjunction with surface waters. The intensive utilization of principal aquifers is monitored by the national monitoring groundwater network. This activity is accomplished by nearly 180 boreholes for different aquifers. The main point of the monitoring strategy is to identify index or signature sites, which would ideally be at locations with long historical records and provide a good representation of conditions in the groundwater body. It would be necessary to show historical trends in water quality through analysis of chemical component data. There would, therefore, be a need to have data for the selected sites in electronic form, and to use chemical and physical sensors for the remote continuous monitoring of the water parameters.

The traditional approach to water quality monitoring consists of manual sampling in remote locations and the transport of samples to the laboratory for chemical analysis. This approach, although simple, is relatively non-technical and easily reproducible. However, it is timeconsuming, has high labor costs, may be limited due to weather conditions, can give inconsistent results, and does not allow for the continual collection of data [3].

Examples of new technology and instrumentation are automatic monitoring stations that are already effectively used in a number of networks for monitoring the "capture" of various pollutants or temporal changes in toxicity [4-9]. Sensor technologies have emerged from environmental sciences in the last couple of decades as a promising tool and are still in their infancy. They now require validation. Water quality monitoring is currently based on standardized laboratory methods. Sensors, despite being developed more recently, do not have the same recognition capacities and are only seldom used, despite their advantages. Field validations are needed in order to boost their credibility [6, 10-12]. ISO standard 15839 (released in 2003) provides a consistent protocol for characterizing these sensors, and should facilitate their adoption for routine use by regulatory bodies. Further work is required to increase their operational period, and particularly to prevent bio-fouling and clogging. Other technological challenges include miniaturization of on-chip modules, cutting energy consumption, developing in-situ fuelling, eco-design, geolocation, communication checking, and data validation and transmission. It is equally imperative to improve data management [10]. The aim of this article is a series of case studies of pollution sources of groundwater quality in the Prut River and of the Chismichioi pesticide landfill in southern Moldova.

\section{Analysis of Groundwater Quality Monitoring in Moldova}

Groundwater status refers to both the quantity and chemical quality of groundwater. Contaminant levels in groundwater are used as the main measure of quantitative status. To achieve good groundwater quantitative status, the available groundwater resource should not show signs of depletion and the ecological quality objectives for groundwater-dependent surface waters should be met. Groundwater chemical status can be measured by determining the principal chemical composition and the 
concentration of pollutants in the groundwater body. This is usually done by referencing threshold concentrations plus EU and U.S. EPA water quality standards, and the environmental objectives associated with surface waters or terrestrial ecosystems. The analysis of water contamination and identification of the water quality parameters were made using various advanced methods: electrochemistry, gas chromatography, atomic absorption spectrophotometer, and a CONSORT C6030 portable laboratory water analyzer equipped with an SE670/G1 toroidal conductivity sensor.
Moldova has aquifer layers composed predominantly of limestone and sandstone in the north and sands to the south, each with discretely different characteristics and different sources of recharge. The Prut River basin includes following principal aquifers (Fig. 1).

- $\mathrm{A}_{3}-$ Alluvial floodplain and terrace deposits

- $\mathrm{N}_{2} \mathrm{p}$ - Pontian sands

- $\mathrm{N}_{1} \mathrm{~S}_{3} \mathrm{~m}$ - Upper Sarmatian-Meotian aquifer group

- $\mathrm{N}_{1} \mathrm{t}-\mathrm{N}_{1} \mathrm{~S}_{1-2}$ - Baden-Sarmatian aquifer group

- $\mathrm{K}$ - Cretaceous limestone

- $\mathrm{S}_{1}-$ Silurian crystalline limestone

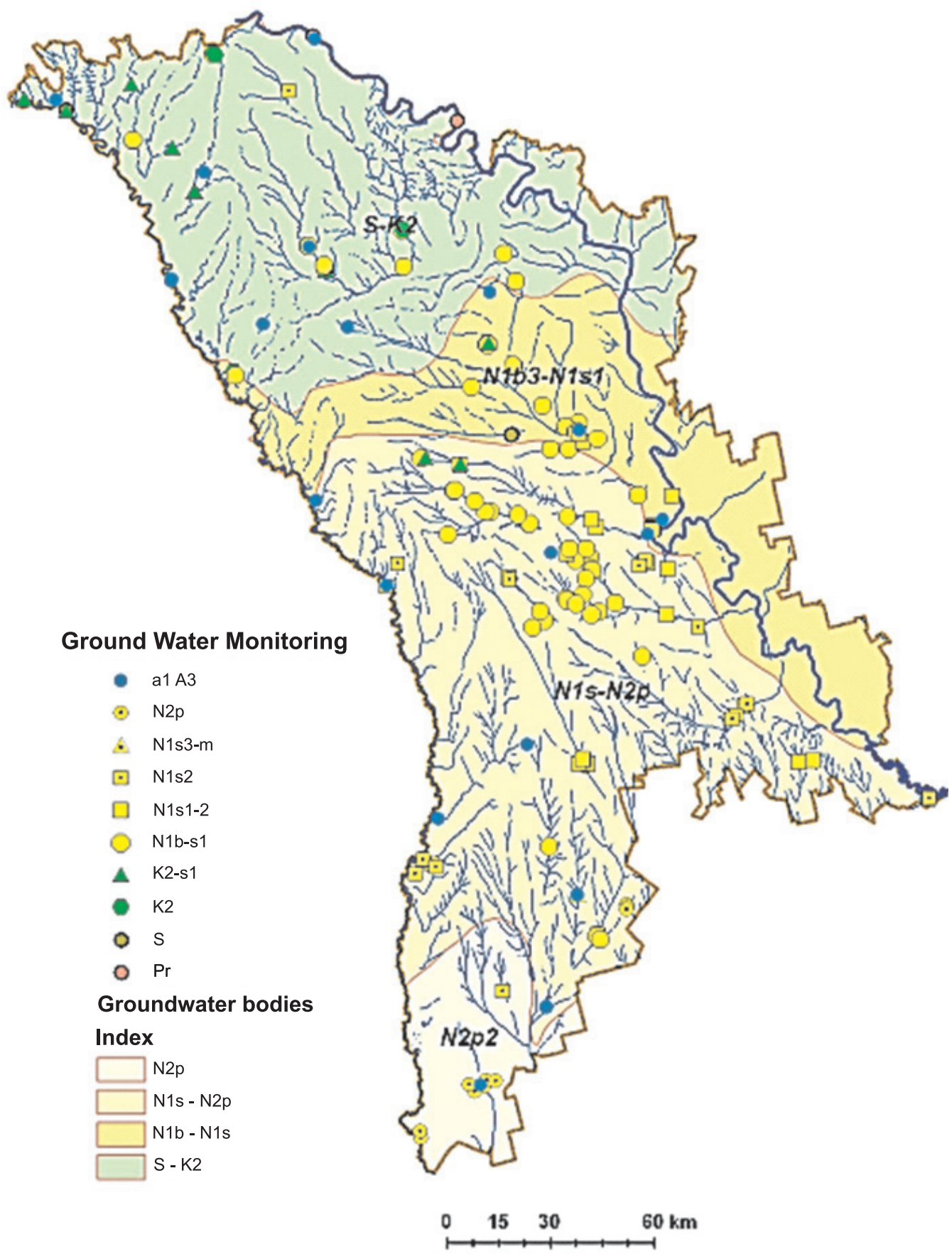

Fig. 1. Groundwater monitoring network in Moldova (source: Five-Year Report: Investigation of Groundwater Regime and Balance Elements during 2005-09, EHgeoM, 2010). 
During 2013-14 a delineation of principal groundwater bodies in this region and their characteristics was created. Groundwater bodies were identified from one or more of the main stratigraphic units, grouping together geological formations with similar properties and hydraulic parameters that have both horizontal and vertical hydraulic continuity. Unfortunately, in recent years the number of observation wells appears to have decreased - from 490 boreholes in 1991 to about 170 in 1997 and 186 in 2010. The last inventory observations were carried out in 186 observation wells at 33 locations, and the level measurements were made once every three days.
The instrumentation includes a Roulette WG-LM-30 and 50, level USAC-GL-150-200, thermometer TM-10, and level measuring tools made in Moldova by EHgeoM. In the last decade, the frequency of sampling groundwater quality has decreased. Previously, in Soviet times, samples were taken from monitoring boreholes at least once a year, and more frequently in areas with complex hydrogeological conditions. Prior to sampling, water from boreholes was pumped out, following the guidelines established by VSEGINGEO (the former Soviet Institute of Hydrogeology and Engineering Geology, Moscow). Two types of groundwater quality analysis are made for

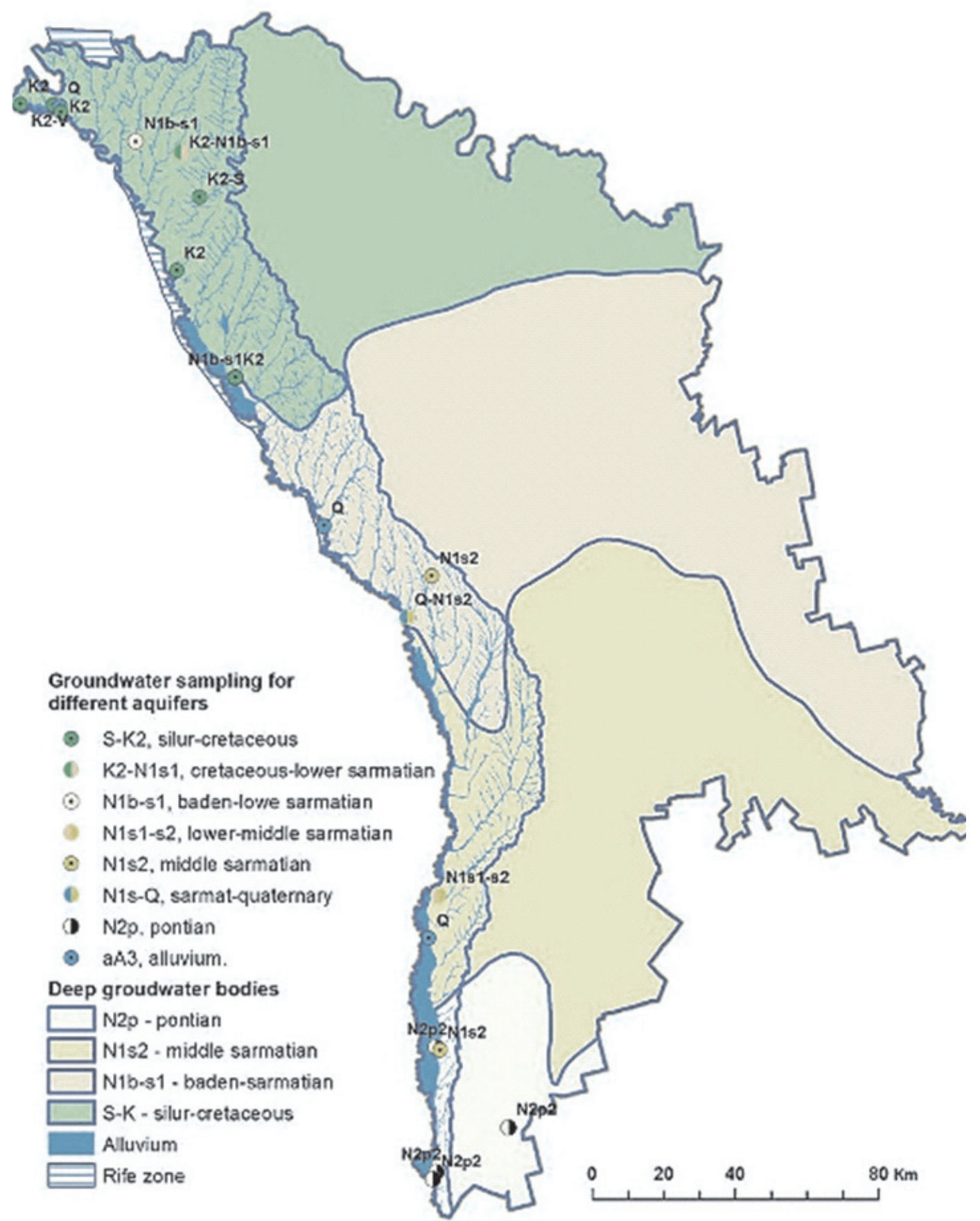

Fig. 2. The location of groundwater samples in the Prut River basin. 
their characteristics:

1. Routine sampling of major ions and physical characteristics: sodium, potassium, calcium, magnesium, ammonia, sulphite, sulphate, bicarbonate, chloride, nitrate, fluoride, methane, taste, odor, turbidity, color, dry residue, total hardness, carbonate, and noncarbonate alkalinity

2. Targeted sampling of micro-components when there is known to be a problem: phosphate, manganese, iron, copper, molybdenum, arsenic, lead, selenium, zinc, aluminum, and beryllium

The actual monitoring network is presented in Fig. 1.

During the five-year period covering 2005-09 there were 123 chemical analyses of major ions and physical parameters: just over half of these samples were collected from operational boreholes, 48 samples from observation boreholes, and 12 samples were collected from dug wells. On average, this represents a monitoring rate of about 25 samples per year, which is extremely low. For example, in Western Europe one public water supply source would have at least a monthly sampling of raw water, and the sampling frequency would be increased if known pollution problems had occurred in the aquifer. The current system in Moldova is therefore grossly inadequate in this respect, and such sampling does not provide effective management.

\section{Case Study of Prut River Groundwater Quality Analysis}

Six main aquifers - 1) Alluvial, 2) Pontian, 3) Meotic, 4) Middle Sarmatian (Congeriev), 5) Baden-Sarma-

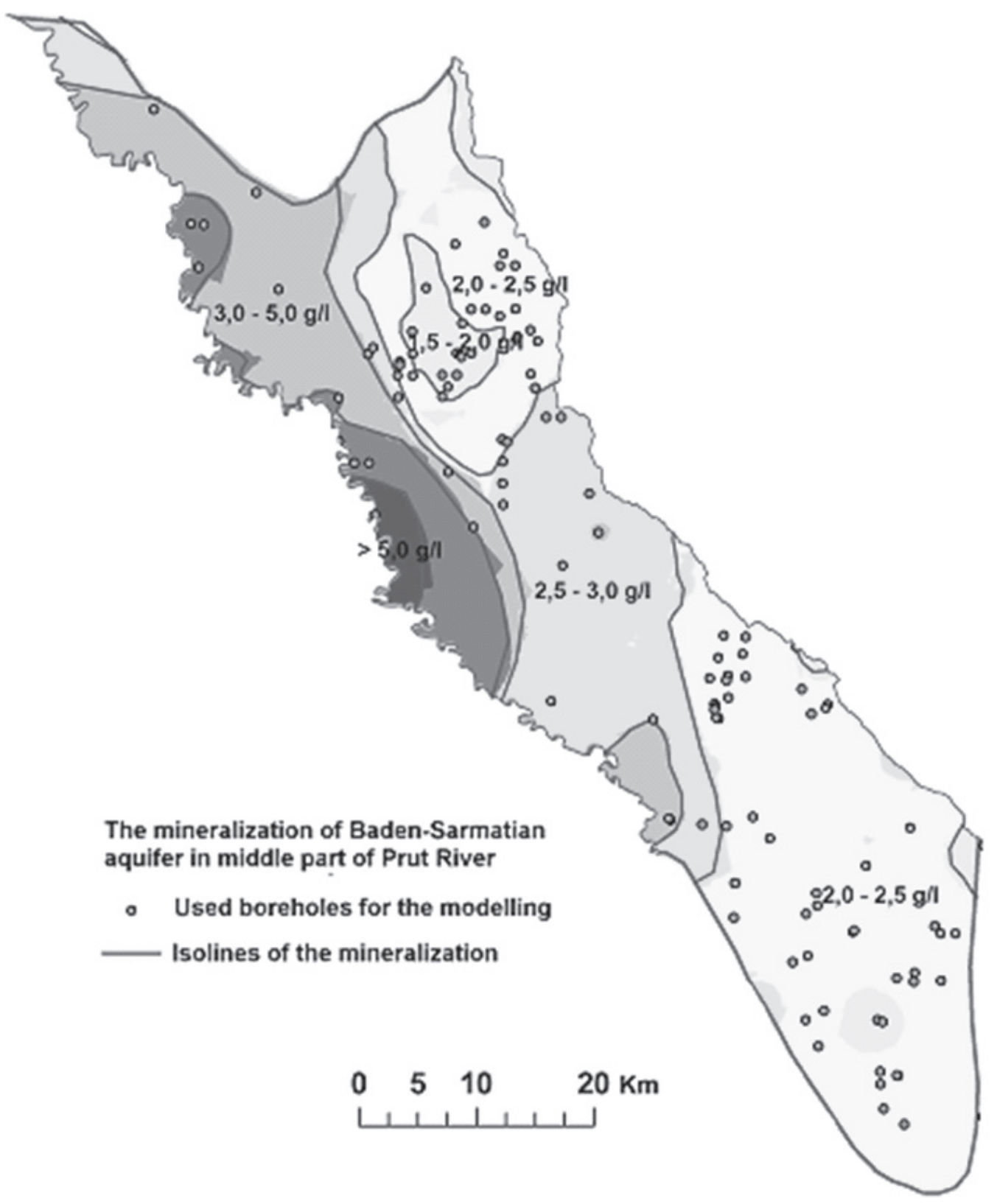

Fig. 3. Mineralization of the Baden-Sarmatian aquifer in the middle part of the Prut River Basin [13]. 
tian, and 6) Cretaceous-Silurian - have been analyzed for groundwater quality. The sampling locations are shown in Fig. 2.

Quaternary sediments fully cover the surface of the pilot basin but are mostly developed in the river valleys. These sediments contain groundwater, and their water-bearing capacity depends on grain size, lithology, hydraulic conductivity, effective thickness, transmissivity, and chemical composition as well as on characteristics of overlaying strata. In most places, quaternary aquifers are hydraulically interconnected with underlying waterbearing sediments making joint groundwater bodies with them. Taking into account hydraulic and hydrochemical characteristics of water-bearing layers, only one Holoceen

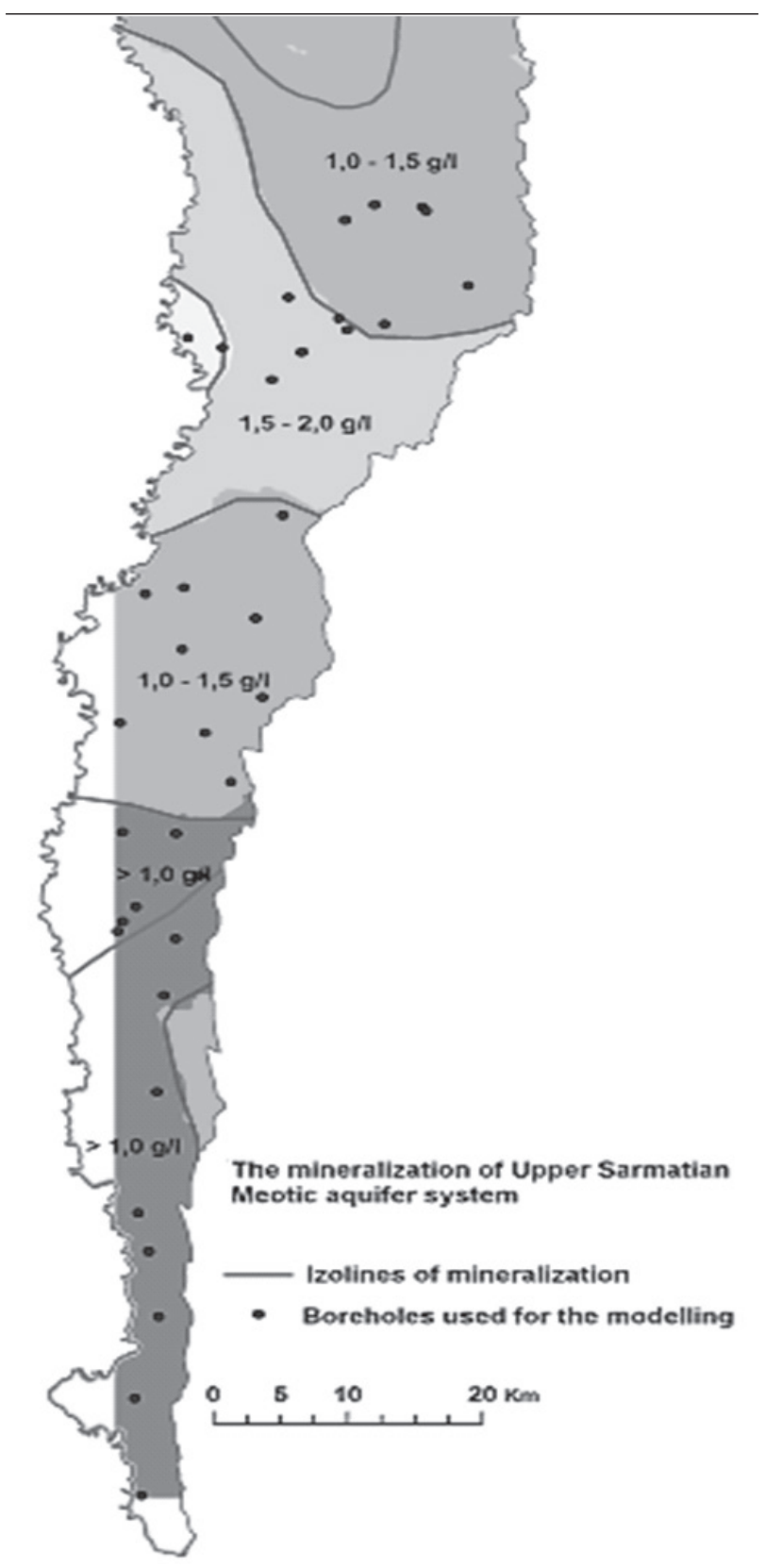

Fig. 4. Mineralization of the Upper-Sarmatian aquifer in the southern part of the Prut River Basin [13]. alluvial aquifer is distinguished as a separate groundwater body in the quaternary aquifers [13].

The Holocene alluvial aquifer in the Prut pilot basin is located in the river valleys including flood plains and all Prut terraces (I-IX terraces) and its tributaries. Groundwater is contained in lithologically and granulometrically heterogeneous pebbles, gravels, and sands mixed with sandy loams. The total thickness of the water-bearing part in alluvial sands and gravels comprise approximately $5 \mathrm{~m}$, sometimes $10-30 \mathrm{~m}$. Aquifer depth varies from $2-3$ to $15-20 \mathrm{~m}$. The aquifer is unconfined and only sometimes on the terraces, which are covered by impermeable alluvial loams, $4 \mathrm{~m}$ high head is observed. The water-bearing capacity of the aquifer is uneven and depends on granulometric composition and lithology of sediments. In Prut flood plains the yields of the wells reach $20 \mathrm{l} / \mathrm{sec}$, and in the valleys of smaller rivers only $1.8 \mathrm{l} / \mathrm{sec}$. Groundwater chemical composition in the contemporary alluvial aquifers is very different. Prevailing ions are hydrocarbonate-calcium and sulphate-calcium, with a mineralization of $1-3 \mathrm{~g} / 1$.

The Baden Sarmatian aquifer system $\left(\mathrm{N}_{1} \mathrm{~b}_{3}+\mathrm{S}_{1}\right)$ is the most widely used aquifer system not only in the pilot basin but in all of Moldova. Water-bearing layers are represented by limestone with layers of fine-grained sand and sometimes clays, marls, and gypsum. The thickness of the aquifer reaches $50 \mathrm{~m}$, in some places up to $90 \mathrm{~m}$, with average thickness of about $25 \mathrm{~m}$. In the northern part of the basin, water-bearing sediments outcrop to the pre-Quaternary surface and these areas coincide with the recharge zones of the aquifer. Groundwater is discharging into the Prut River Valley. Southward, the Baden-Sarmatian aquifer occurs deeper and near the village Gotesht, where it was detected by drilling to a depth of $572 \mathrm{~m}$.

When water-bearing rocks are composed of limestone they contain fresh or slightly mineralized hydrocarbonatecalcium-sodium water with mineralization below $1 \mathrm{~g} / \mathrm{l}$. Such areas, however, are rather scarce and groundwater with mineralization above $1 \mathrm{~g} / \mathrm{l}$ prevails in the basin. The high mineralization (2-3 g/l) is caused by gypsum minerals that are often found in the water-bearing rocks of BadenSarmatian (Fig. 3).

The Upper Sarmatian Meotic aquifer system $\left(\mathrm{N}_{1} \mathrm{~S}_{3} \mathrm{~m}\right)$ is only partially exploited for groundwater abstraction in the southern part of the Prut basin. The deposits in that area are represented by fine-grained sands and clay with the lenses of quartz sand with a total thickness of the aquifer of 60-70 m. This sand is water-bearing and contains good quality water. The thickness of water-bearing layers is 4-5 $\mathrm{m}$. Yields of exploitation wells vary between 3 and $7 \mathrm{~m}^{3} / \mathrm{h}$. Waters from the aquifer system are supplying the needs of several enterprises. Near the Prut River valley yields of the wells increase to $10 \mathrm{~m}^{3} / \mathrm{h}$ with the drawdown of up to $30 \mathrm{~m}$.

The Sarmatian-Meotic aquifer contains hydrocarbonate-sodium waters with total mineralization of 1-1.5 g/l. In some areas, the chemical composition changes to sulphate-hydrocarbonate-sodium and mineralization increases to $2 \mathrm{~g} / \mathrm{l}$ (Fig. 4). The hydraulic parameters of 
the aquifer are rather poor: hydraulic conductivity varies between $0.8-5 \mathrm{~m} /$ day with mean values of $2.3 \mathrm{~m} /$ day and transmissivity changes in a range of $10-25 \mathrm{~m}^{2} /$ day, with the mean being $5 \mathrm{~m}^{2} /$ day. The monitoring results over three wells for the period from 2005 to 2009 indicate a decrease in the level of groundwater. The rate of decrease is from 0.5 to 1.4 meters per year. This can be attributed to an increase in the water abstraction from the operating wells located in the vicinity.

The Middle Sarmatian (Congeriev) aquifer $\left(\mathrm{N}_{1} \mathrm{~S}_{2}\right)$ is used for a centralized water supply in the southern part of the country. The groundwater is contained in fine-grained sands with interlayers of clays, sandstones, and limestone. The thickness of water-bearing sediments varies from $5-15 \mathrm{~m}$ to $40-50 \mathrm{~m}$ with mean values of $20-30 \mathrm{~m}$. The hydraulic properties of water-bearing sands are quite poor. Hydraulic conductivity changes from 0.6 to $1.9 \mathrm{~m} /$ day with average value $1.3 \mathrm{~m} /$ day. The transmissivity values are also very low and do not exceed $20-50 \mathrm{~m}^{2} /$ day. The depth to groundwater aquifer depends on the landscape and varies from 1.5 to $100 \mathrm{~m}$. The yields of wells vary from 5 to 75 l/s. When hydrocarbonate-sulphate-chloride anions dominate in groundwater, its mineralization is below $1.5 \mathrm{~g} / \mathrm{l}$. When chloride-hydrocarbonate and sodium ions prevail, total mineralization increases up to $2 \mathrm{~g} / \mathrm{l}$ (Fig. 5).

Groundwater from the aquifer is used for drinking and agricultural water supply in the southern part of the basin, although its chemical quality is not favorable for consumption. Monitoring the aquifer indicates a slight decrease in groundwater level with the rate of 0.4 to 0.65 $\mathrm{m}$ per year. The Pontian aquifer $\left(\mathrm{N}_{2} \mathrm{p}\right)$ is spread in the southern part of the pilot area. Water-bearing sediments are composed of sandy clays with interlayers of sand and shell limestone with total thickness of 70-80 m. Prevailing hydraulic properties of water-bearing sands are rather poor. Hydraulic conductivity changes from 3.5-3.7 with mean values of $3 \mathrm{~m} /$ day. The Transmissivity coefficient

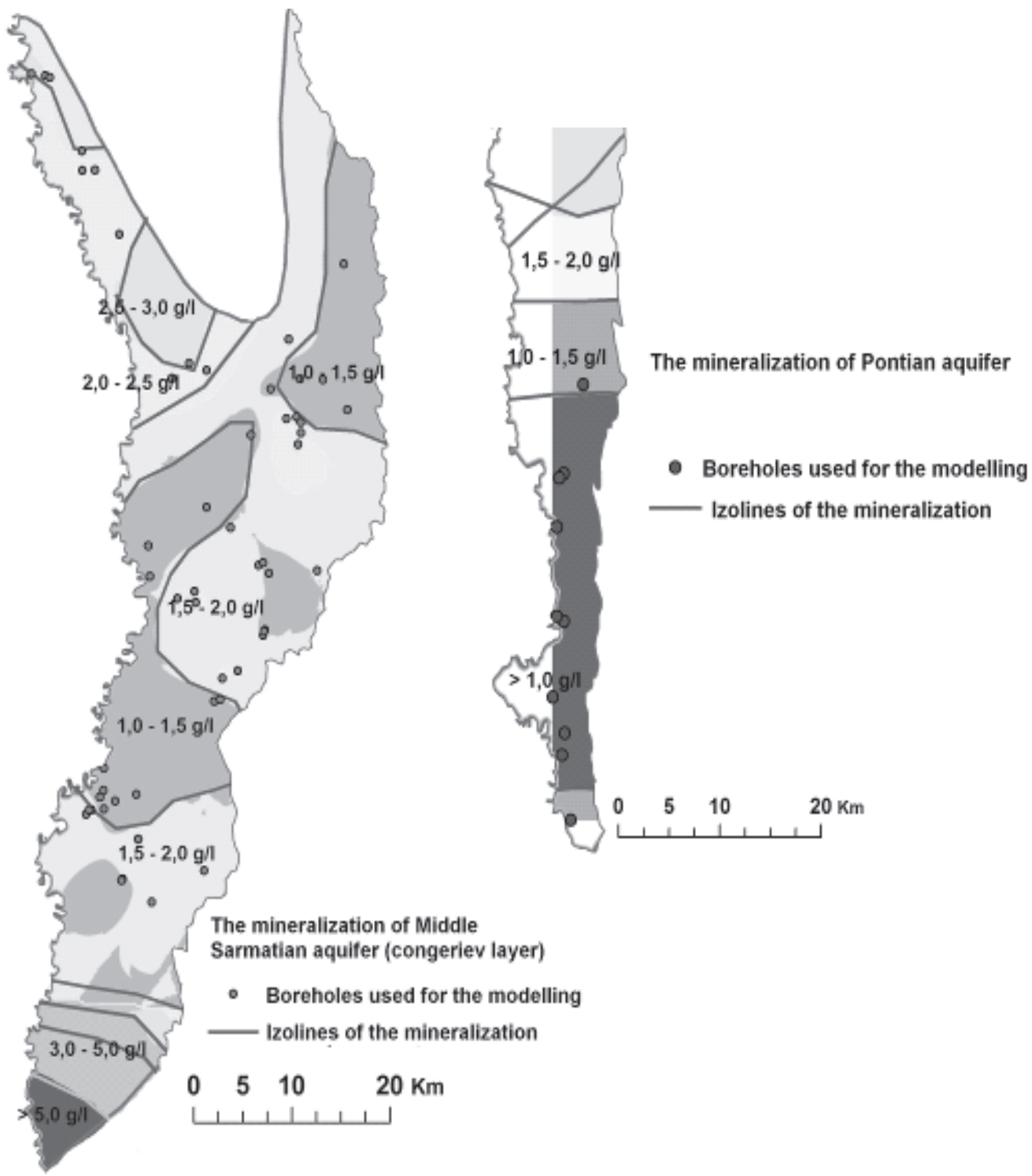

Fig. 5. The mineralization of middle Sarmatian and Pontian aquifers in the southern part of the Prut River Basin [13]. 


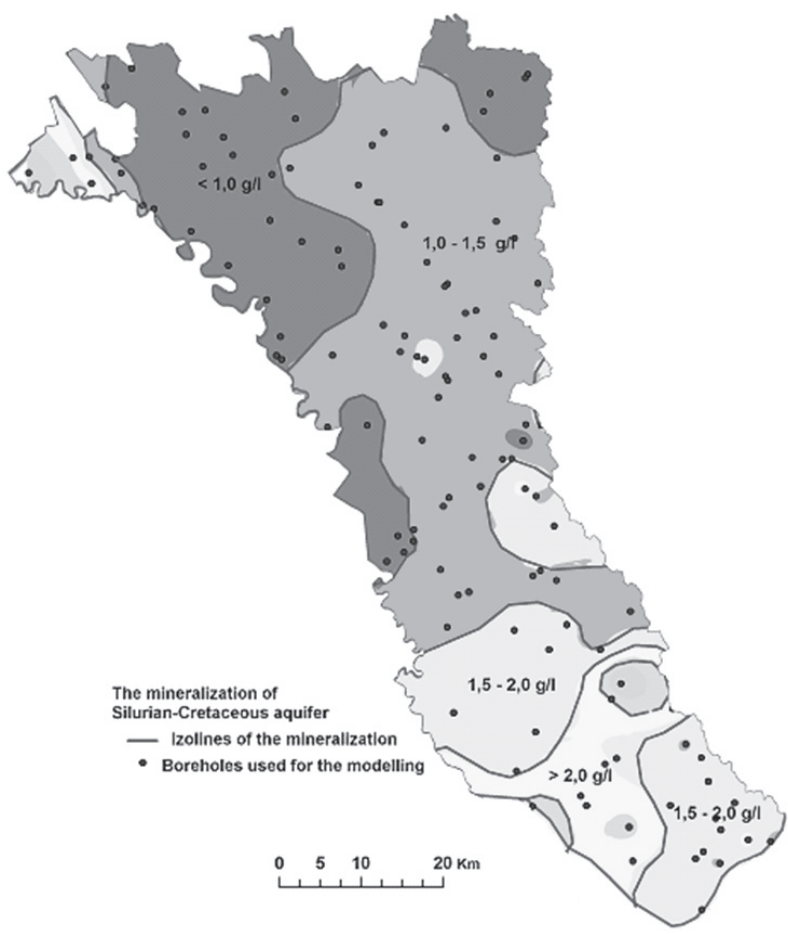

Fig. 6. The mineralization of the Silurian-Cretaceous aquifer in the northern part of the Prut River Basin Silurian-Cretaceous aquifers are hydraulically connected with the Baden-Sarmatian groundwater system. Groundwater from both bodies is widely used for the centralized and local water supplies. varied between $18-45 \mathrm{~m}^{2} /$ day in some places (e.g. Giurgiulesti Village), increasing to $250-260 \mathrm{~m}^{2} /$ day. The depth to groundwater aquifer depends on the landscape and varies from 2 to $125 \mathrm{~m}$. The yields of wells vary from $1.1-2.3 \mathrm{l} / \mathrm{s}$, increasing southwards to $3.7-7.6 \mathrm{l} / \mathrm{s}$. Near the village of Taraklia, a few springs are discharging into the Prut River Valley with the capacity of 8-9 1/s. The aquifer contains fresh groundwater with mineralization $<1 \mathrm{~g} / \mathrm{l}$ (Fig. 5) and prevailing ions of hydrocarbonate-sulphatechloride-sodium, sometimes sulphate-hydrocarbonatesodium. Groundwater from the aquifer is used for drinking and agricultural water supply in the southern part of the basin.

The Silurian-Cretaceous aquifer system $\left(\mathrm{S}_{2}-\mathrm{K}_{2}\right)$ is spread across the whole territory of the pilot basin but is used for centralized water supply only in the northern part of the basin (Lipcani, Briceni, Edineț, Rîşcani). The groundwater is contained in limestone and sandstone, with interlayers of Silurian marls and argillites with total thickness varying from $50-60 \mathrm{~m}$ to $100-120 \mathrm{~m}$. The waterbearing capacity of the aquifers varies across a wide range. The dominating values of hydraulic conductivity and transmissivity are rather low $(\mathrm{K}=0.12-0.37 \mathrm{~m} /$ day, $\mathrm{Km}=10-50 \mathrm{~m}^{2} /$ day) but in the central part of the basin (Floresti, Belc, Chisinau) the yields of the wells may reach $40-120 \mathrm{~m}^{3} / \mathrm{h}$ with the drawdowns only 10-20 m. The chemical composition of Silurian-Cretaceous aquifers is also heterogeneous. In the northern part of the

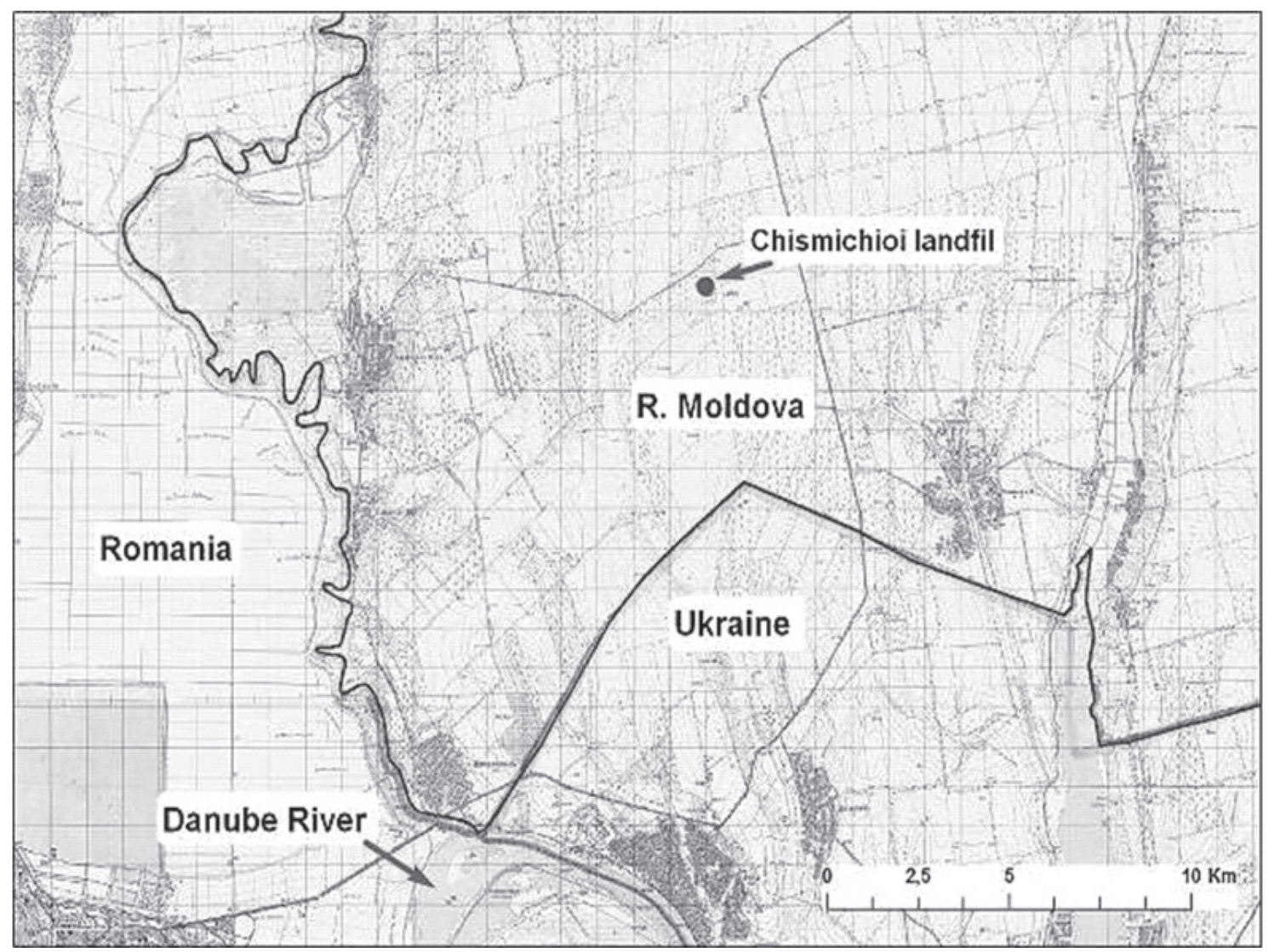

Fig. 7. The location of Chismichioi pesticide landfill in southern Moldova. 


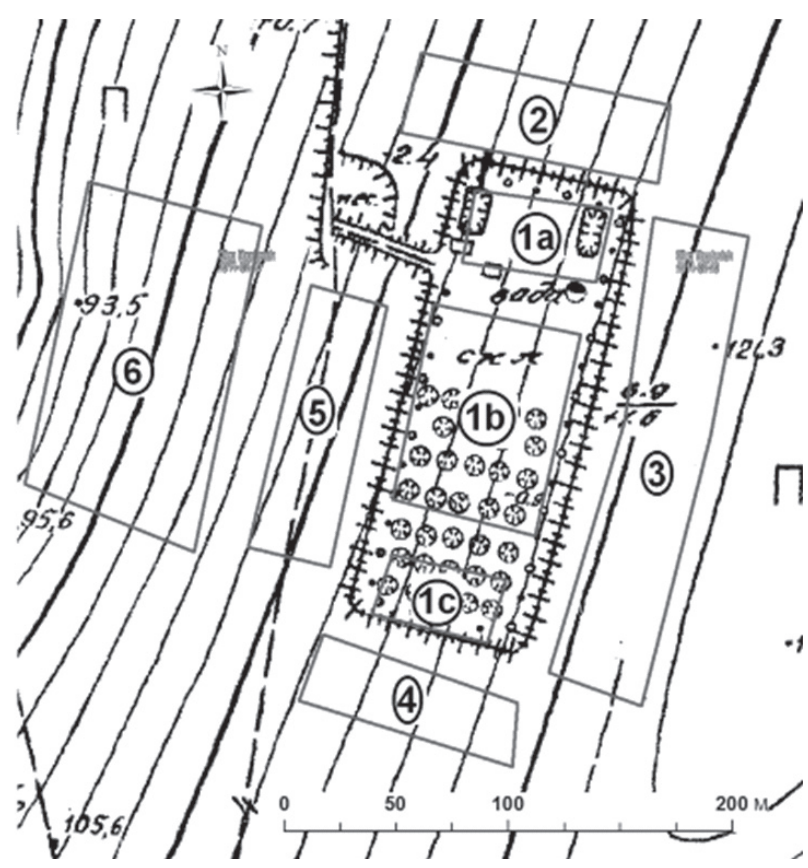

Fig. 8. The sampling plan for the study of the impact of Chismichioi pesticide landfill to the environment and water resources.

basin fresh groundwater with mineralization $<1 \mathrm{~g} / 1$ and dominating hydrocarbonate-sulphate-calcium-magnesium ions are detected (Fig. 6). Going to the south, the chemical composition of the aquifer is changing to hydrocarbonatesulphate-sodium and hydrocarbonate sodium type and the amount of total dissolved solids increases to $2-10 \mathrm{mg} / \mathrm{l}$.

\section{Evaluation of Pollution Impact on Chismichioi Pesticide Landfill Water Quality}

One old pesticide burial storage (Chismichioi) was studied by different projects at the southern part of the Moldova close to the boundary with Ukraine and the Danube River (Fig. 7). It has the biggest deposit of toxic substances in the Low Danube Euro region: nearly 3.3 thousand tons of obsolete toxic pesticides (unofficially near 32,000 tons). In this study we presented a trial made in 2013 under the financial support of the National Ecological Foundation of the Republic of Moldova.

Several zones around this landfill were sampled by the methodology of incremental sampling and analyzed in the accredited laboratory for the content of toxic pesticides in soil samples using gas chromatography. The sampling plan is presented on Fig. 8. Zone 1a is a territory of persistent organic pollutants (POPs). Every studied area was sampled by three complex samples; every complex sample has 30-40 subsamples. Zones $1 \mathrm{a}, 1 \mathrm{~b}$, and $1 \mathrm{c}$ were sampled for three complex samples for different locations of the sarcophaguses. Zone 1a was sampled at a depth of 0-5 $\mathrm{cm}$ and 40-60 $\mathrm{cm}$ at sarcophagus bodies, and for the territory between sarcophaguses at a depth of 0-20 cm. Zone $1 \mathrm{~b}$ was sampled for depth $0-5 \mathrm{~cm}$ at sarcophagus bodies and for depth 0-20 cm between sarcophagus bodies. Zone $1 \mathrm{c}$ was sampled for three intervals for the entire territory because there were not separate sarcophagus: $0-5 \mathrm{~cm}$, $5-20 \mathrm{~cm}$, and 40-60 cm.

The following spectrum of POPs was identified in 33 complex soil samples: 4-4-DDE (CAS \#: 72-55-9, dichlorodiphenyldichloroethylene); 2-4-DDD (CAS \#: 5319-0, mitotane) 4-4-DDD (CAS \#: 72-54-8, 1,1-dichloro-2,2-bis(p-chlorophenyl)ethane); 2-4-DDT (CAS \#: 789-02-6, benzene, 1-chloro-2-[2,2,2-trichloro-1-(4-chlorophenyl)ethyl]-); 4-4-DDT (CAS \#: 50-29-3, benzene, 1,1'-(2,2,2-trichloroethylidene)bis[4-chloro-); a-HCH (CAS \#: 319-84-6 $\alpha$-Hexachlorocyclohexane), b-HCH (CAS \#: 608-73-1, $\beta$-hexachlorocyclohexane), and g-HCH (CAS \#: 319-86-8, $\gamma$-hexachlorocyclohexane). The other toxic organic substances studied at this site are: PAHs (polycyclic aromatic hydrocarbons), triazine pesticides, and some heavy metals. The total POPs concentrations in different sampling zones (Fig. 8) from the pesticide landfill are presented in Table 1.

The maximum POPs concentrations up to $56.0 \mathrm{mg} /$ $\mathrm{kg}$ were determined in zone 1a at soil depth of $0-20 \mathrm{~cm}$ between sarcophaguses. The sarcophagus bodies are

Table 1. The concentrations of POP substances in complex soil samples from Chismichioi landfill.

\begin{tabular}{|c|c|c|c|c|}
\hline \multicolumn{2}{|c|}{ Sectors in Landfill Perimeter } & \multicolumn{2}{c|}{ Outside Sectors } \\
\hline Sector index & Depth, cm & Total POPs, mg/kg & Sector index & Total POPs, mg/kg \\
\hline Sector 1 a & $0-5$ & 0.420 & Sector 2 & 0.060 \\
\hline Sector 1 a & $40-60$ & 1.920 & Sector 3 & 0.033 \\
\hline Sector 1 a & $0-20$ & 56.005 & Sector 4 & 0.080 \\
\hline Sector 1 b & $0-5$ & 0.318 & Sector 5 & 0.040 \\
\hline Sector 1 b & $0-20$ & 4.522 & Sector 6 & 0.050 \\
\hline Sector 1 c & $0-5$ & 20.591 & & \\
\hline Sector 1 c & $5-20$ & 36.9423 & & \\
\hline Sector 1 c & $40-60$ & 1.1040 & & \\
\hline
\end{tabular}


covered by relatively clean soil with POPs contamination $0.42 \mathrm{mg} / \mathrm{kg}$. The level of POPs pollution increases after $50 \mathrm{~cm}$ of the soil layer. POP concentrations in the interval $40-60 \mathrm{~cm}$ is $1.92 \mathrm{mg} / \mathrm{kg}$. This area is characterized by the burial of the highest toxic substances: DDTs, $\mathrm{HCH}$, heptachlor, chlordane, etc. The situation with pollution levels are not changed strongly from the burial time (late 70 's). The territory between sarcophaguses is heavily polluted. The solution for this situation is to add an additional clean soil layer.

The second zone by the pollution level is 1c. This zone has a larger pollution spectrum and POPs pollution level in the interval from 1.1 to $36.94 \mathrm{mg} / \mathrm{kg}$. This zone is characterized by poor sarcophagus construction. The polluted soil and pesticide residuals are buried in a high soil layer in the interval $0-50 \mathrm{~cm}$. The next zone for pollution level is $1 \mathrm{~b}$. Here the pollution level at sarcophagus bodies is relatively low. Only the territory between sarcophaguses is polluted with a middle value of $4.52 \mathrm{mg} / \mathrm{kg}$.

The neighboring territories are not strongly polluted by POPs. The concentration of these substances in soil samples is in the interval $0.033-0.080 \mathrm{mg} / \mathrm{kg}$, which is lower than the admissible level for soil by government regulation. The analysis of groundwater from a monitoring well near this site does not show pollution by toxic pesticides. The risk of environmental pollution exists from a contaminated top layer of soil from zones $1 \mathrm{a}$ and $1 \mathrm{c}$. The recommendation was to cover polluted areas by pure soil with thickness near $0.5 \mathrm{~m}$.

\section{Conclusions}

Due to ageing infrastructure and inefficient filtration processes, surface water contamination has contributed significant contamination to groundwater bodies in Moldova. Long-term monitoring of groundwater contamination and its perpetual monitoring is conducted within the framework of NATO project EAP.SFP.984403. The outcome directly correlates with surface water contamination. The following conclusions were made for the monitoring of water contaminants in Moldova:

- The groundwater monitoring network is working and principal aquifers and groundwater bodies are characterized by their quality and quantity parameters at the minimal level.

- Natural pollutants are analyzed by respective institutions according to routine sampling procedure, but the sampling rate is not sufficient for the actual requirements of EU and other international regulations.

- The modeling of water quality parameters (mineralization) obtained for operational boreholes showed natural conditions for delineated groundwater bodies and can be used for the design of development of the groundwater monitoring network.

- Modern approaches are required for the monitoring of water quality and quantity by the utilization of chemical sensors and remote sensing.

- Monitoring and evaluation of different pollution sources is required for ensuring the safety and security in water resource and environmental protection.

\section{Acknowledgements}

Our work was supported by SciNetNatHazPrev project No. TR11C1.01-02/309 and NATO project No. EAP.SFP.984403.

\section{References}

1. MOSS B. The Water Framework Directive: Total environment or political compromise? Sci. Total Environ. 400, 32, 2008.

2. SODERSTROM H., LINDBERG R.H., FICK J. Strategies for monitoring the emerging polar organic contaminants in water with emphasis on integrative passive sampling. Journal of Chromatography A, 1216, 623, 2009.

3. MIJOVIĆ S., PALMAR B. Water Quality Monitoring Automation of Rivers in Serbia. Facta Universitatis. Working and Living Environmental Protection. 9 (1), 1, 2012.

4. BOURGEOIS W., ROMAIN A.C., NICOLAS J., STUETZ R.M. The use of sensor arrays for environmental monitoring: interests and limitations. Journal of Environmental Monitoring 5, 852, 2003.

5. BRIDGE J. High resolution in-situ monitoring of hyporheic zone biogeochemistry Bristol (UK): Environment Agency. $51,2005$.

6. HORSBURGH J.S., SPACKMAN JONES A., STEVENS D.K., TARBOTON D.G., MESNER N.O. A sensor network for high frequency estimation of water quality constituent fluxes using surrogates. Environmental Modelling and Software. 25, 1031, 2010.

7. KOT-WASIK A., ZABIEGALA B., URBANOWICZ M., DOMINIAK E., WASIK A., NAMIESNIK J. Advances in passive sampling in environmental studies. Anal. Chim. Acta. 602, 141, 2007.

8. VASEASHTA, A., BRAMAN, E., SUSMANN, P, DEKHTYAR, YU., PEROVICHA, K. Sensors for Water Safety and Security, Электронная обработка материалов, 48 (5), 120, 2012.

9. WINKLER S., ZESSNER M., SARACEVIC E., FLEISCHMANN N. Intelligent monitoring networks - transformation of data into information for water management. Water Sci. Technol. 58, 317, 2008.

10. NAMOUR P., CLEMENT Y., BREIL, P. LANTERI, P, JAFFREZIC-RENAULT, N. Environmental monitoring and water safety are claiming innovative tools. Novatech, Lyon, France. 8 p. $<$ hal-00951655> https://hal.archives-ouvertes. fr/hal-00951655, 2013.

11. WINKLER S., BERTRAND-KRAJEWSKI J.L., TORRES A., SARACEVIC, E. Benefits, limitations and uncertainty of in situ spectrometry. Water Sci. Technol. 57, 1651, 2008.

12. YANG W., NAN J., SUN D. An online water quality monitoring and management system developed for the Liming River basin in Daqing, China. Journal of Environmental Management. 88, 318, 2008.

13. PAUKSTYS B., BOGDEVICH O., IURCIUC B. Identification, Characterization and Delineation of Groundwater Bodies in Prut River Basin, Republic of Moldovam Report. Environmental Protection of International River Basins Project, Contract No. 279-666, 2013. 